Article

\title{
Sustainable Management Practices and Stakeholder Pressure: A Systematic Literature Review
}

\author{
Fazli Haleem ${ }^{1}$, Sami Farooq ${ }^{2}$, Yang Cheng ${ }^{3}$ and Brian Vejrum Waehrens ${ }^{3, *}$ (i) \\ 1 Department of Management Sciences, Shaheed Benazir Bhutto University, Khairpur 18000, Pakistan; \\ haleem@sbbu.edu.pk \\ 2 School of Management Sciences, Ghulam Ishaq Khan Institute of Engineering Sciences and Technology, \\ Topi 23640, Pakistan; sami.farooq@giki.edu.pk \\ 3 Deptartment of Materials and Production, Aalborg University, 9220 Aalborg, Denmark; cy@mp.aau.dk \\ * Correspondence: bvw@mp.aau.dk
}

Citation: Haleem, F.; Farooq, S.; Cheng, Y.; Waehrens, B.V. Sustainable Management Practices and Stakeholder Pressure: A Systematic Literature Review. Sustainability 2022, 14, 1967. https://doi.org/10.3390/ su14041967

Academic Editor: Carlos Rodríguez Monroy

Received: 9 January 2022

Accepted: 2 February 2022

Published: 9 February 2022

Publisher's Note: MDPI stays neutral with regard to jurisdictional claims in published maps and institutional affiliations.

Copyright: (C) 2022 by the authors. Licensee MDPI, Basel, Switzerland. This article is an open access article distributed under the terms and conditions of the Creative Commons Attribution (CC BY) license (https:// creativecommons.org/licenses/by/ $4.0 /)$.

\begin{abstract}
This paper aims to summarize and analyze what is known regarding the ways in which stakeholder pressure may influence sustainable practices. Furthermore, this study extends this understanding to the development of several research opportunities for further investigation. A systematic extensive literature review was performed to investigate the relationship between stakeholder pressure and sustainable management practices. This literature review shows that organizational factors are more widely covered than the individual and macro-level factors as moderating variables, and suggests more organizational-, individual-, and macro-level factors, as well as the interaction of these factors as moderating variables on the link between stakeholder pressure and sustainable management practices. Furthermore, the use of the stakeholder theory is dominant, followed by the use of the institutional theory. The manufacturing sector is widely covered, survey methodology is extensively used, and the environmental dimensions are more addressed than the social dimensions of sustainability. The relationship between stakeholder pressure and the adoption of sustainable management practices is not obvious, due to the varied results. Therefore, it is difficult to establish a direct relationship between stakeholder pressure and the adoption of sustainable management practices. This study furthers insight into the stakeholder pressure influence on sustainable management practices by reviewing the comprehensive literature and suggesting future research opportunities.
\end{abstract}

Keywords: literature review; sustainability; social responsibility; sustainable management practices; stakeholder pressure; triple bottom line

\section{Introduction}

The globalization of business operations comes with many negative effects, including rising social inequalities, soaring disparities in income, and global environmental and social problems [1]. Global concerns about environmental and social challenges resulted in forceful voices from different stakeholders, affecting the institutional environments in which companies operate, as well as increasing the pressure on companies to address the environmental and social impacts of not only their own operations, but also their wider supply chain's operations [2]. Despite the increasing stakeholder pressure, companies often do not conform to the stakeholder expectations [3] and the implementation of sustainable practices often trails behind the communication [4]. Consequently, the broader social concerns of corporate social responsibility and environmental responsibility have currently become dominant themes in both theory and practice [5]. Despite the corporations' efforts to implement social and environmental concerns, a gap exists between the communication and the sustainability implementation in practice [4].

Stakeholder pressures play a crucial role in enhancing, or hindering, the adoption of sustainable management practices. Stakeholders are defined as any individual or group that can affect, or be affected, by an organization [6]. The stakeholder theory argues for a 
fit between the values of the corporation and its managers, as well as the expectations of stakeholders and the societal issues that will determine the ability of the firms to sell their products [7]. The stakeholder approach focuses on the management of the business environment, its relationships, and the promotion of shared interests, which, in turn, impacts long-term survival [8]. The literature points out that it is the different types of stakeholders, namely, competitors, governments, communities, non-governmental organizations (NGOs), and customers that press firms to adopt sustainable management practices [9-11]. The effect of different stakeholders is different, and stakeholders use different mechanisms to influence the adoption of sustainable management practices. For instance, external stakeholders, including governments, NGOs, and communities can regulate or mobilize public opinion [12], and pressure from internal stakeholders, such as employees and managers, could lead to proactive environmental strategies [13]. Internal and external stakeholders make up the diversified range of stakeholders. However, in this study, "stakeholders" refer to external stakeholders, i.e., the study focuses on the influence of external pressure from stakeholders on the adoption of sustainable management practices. As a result, we delimit the study from stakeholders within the organization, and instead, assess aggregate external stakeholder pressures without separating the pressure from the particular types of stakeholders. By sustainable management practices/social responsibility, we imply that environmental and social issues/practices, either inside the supply chain, or both inside and outside the supply chain, can influence strategies. Though stakeholder pressure is considered one of the most important determinants that influence the adoption of sustainable management practices, there is controversy about whether stakeholder pressure is positively related to the adoption of sustainable management practices. Many studies have produced contradictory findings in their research on the relationship between stakeholder pressure and the adoption of sustainable practices. For instance, the majority of the previous studies reported positive effects of stakeholder pressure on the implementation of sustainable management practices [14,15]; however, a few studies show no relationship (e.g., $[10,16])$. The relationship between stakeholder pressure and adoption of sustainable management practices is not obvious, given the varied results. Consequently, there is difficulty in defining the direct relationship between stakeholder pressure and the adoption of sustainable management practices. While establishing a link between stakeholder pressure and the adoption of sustainable management practices provides an important contribution, the specific boundary conditions surrounding the relationship remains unclear and needs further research. This is supported by Meixell and Louma [17], who called for a further investigation into the circumstances surrounding the relationship between stakeholder pressure and the adoption of sustainable management practices.

Over the last 20 years, many studies have reported on sustainability. Many researchers conducted literature reviews on sustainability (e.g., [18-21]). However, to the best of our knowledge, there is only one study by Meixell and Louma [17], which addresses the effect of stakeholder pressure on the adoption of sustainable management practices. In their review, these authors presented a conceptual model on the influence of stakeholder pressure on sustainable management practices. This paper aims to provide a systematic literature review on the relationship between stakeholder pressure and the adoption of sustainable management practices. More specifically, we aim to explore the following question: How and when does stakeholder pressure affect the adoption of sustainable management practices? This study adds to the discussion regarding the boundary conditions surrounding the link between stakeholder pressure and the adoption of sustainable management practices, and provides research directions.

The paper is structured as follows: first, we explain the methodology used for the literature review; then, the results and discussion of the literature review are described; and, finally, the conclusions and future research directions are presented. 


\section{Literature Review Methodology}

This study follows a systematic review approach. According to Fink [22] "a research literature review is a systematic, explicit, and reproducible method for identifying, evaluating, and synthesizing the existing body of completed and recorded work produced by researchers, scholars, and practitioners." In this type of review, the investigator "locates existing studies, selects and evaluates contributions, analyses and synthesizes data, and reports the evidence in such a way that allows reasonably clear conclusions to be reached about what is and is not known," [23]. A systematic review provides a summary of themes, issues, and theoretical contents in a specific research field [24]. Furthermore, a systematic literature review discusses theoretical and methodological strengths and weaknesses within a research field and analyzes the current findings concerning a research question [25,26]. This section describes the use of these methodological principles, addresses article selection, coding, and the resulting quantitative and qualitative analyses. For the analysis, we followed the recommendations by Denyer and Tranfield [23] and went beyond the mere description of the papers included in this study. The screening methodology that was used in this study consisted of the following steps. First, we decided on the keywords to be used in this study. The keywords related to pressure included "stakeholder pressure", "external pressure", and "institutional pressure". Keywords concerning sustainable practices included "sustainable practices", "environmental practices", "green practices", "socially oriented practices", "corporate social responsibility", "sustainability", "corporate citizenship", "green purchasing", "green logistics", and "corporate social and environmental practices". We selected relevant databases, including ABI/ProQuest, Science Direct, Web of Science, Scopus, and Emerald, for searching for the relevant literature to frame this research. By using these databases, this study retrieved the most significant number of articles compared to other studies, which rely on one or a few of these databases. Given the vast coverage of research articles, many researchers have used these databases (e.g., [4]). After defining the keywords and databases, the keywords were searched, along with their acronyms, by using the Boolean logic in the above-mentioned databases. Furthermore, wild cards "**" were used to collect possible variations of the keywords into various blocks, which was searched in five databases used in this study in December 2017. To include more recent research publications, the literature search was repeated and extended into December 2018, 2019, 2020, and 2021.

We started from the year 2000 because, after this period, most of the literature on the pressure and the adoption of sustainable practices started appearing. This extended into the year 2021 to consider all the relevant and updated literature. We targeted, primarily, the peer-reviewed journal articles (original, review, published, and in press) written in English, with a focus on stakeholder pressure and the adoption of sustainable management practices. Considering only the peer-reviewed journals excluded the gray literature, such as book chapters, conference papers, and any other materials. Peer review articles undergo thorough critical reviews before publication that establish controlling mechanisms [27], while other literature does not always pass such a comprehensive process [28]. In particular, conference papers are published in large amounts, and they contribute to the literature reviews in a small scale [29]. Furthermore, we examined journals for this review based on the 2019 Australian Business Deans Council (ABDC) Journal Quality List, which is a well-recognized journal ranking source for all business and management discipline journals [30]. As sustainability is an interdisciplinary and rapidly evolving field, it was considered important to include relevant journals which fell outside the scope of this review, such as the most current and relevant research [31]. The lists of references in the articles were used to identify other relevant research, which was not found by the keyword search previously. To ensure a high-quality review, a second researcher repeated this procedure of material extraction. This step produced 640 papers. By using the EndNote software, all the duplicated results were removed; thus, the final number of articles was reduced to 500 . We checked these articles for their definitional fit. For this purpose, we used the title, keywords, and abstract of each article. Particularly, we carefully read the abstract of 
these papers, focusing on whether the paper addresses the effect of stakeholder pressure on the adoption of sustainable practices. Documents that were not relevant to this study were excluded and we were left with 300 papers. As the decisions about inclusions and exclusions were relatively subjective, all the authors conducted this stage of the systematic review. Tranfield et al. [32] recommends this stage to be performed by more than one reviewer. Lastly, we fully read each article and selected those that could provide insight to the research question. After detailed reading, some articles were found to not fit the purpose of this study, given that these documents did not have a strong relationship with the research topic and provided unclear interpretations that did not significantly contribute to the research topic. After this final screening, only 212 papers remained (see Appendix A), which made up the final portfolio. Figure 1 depicts the screening methodology followed in this study. All these documents were used to lay the theoretical ground for this research and answer the research question.

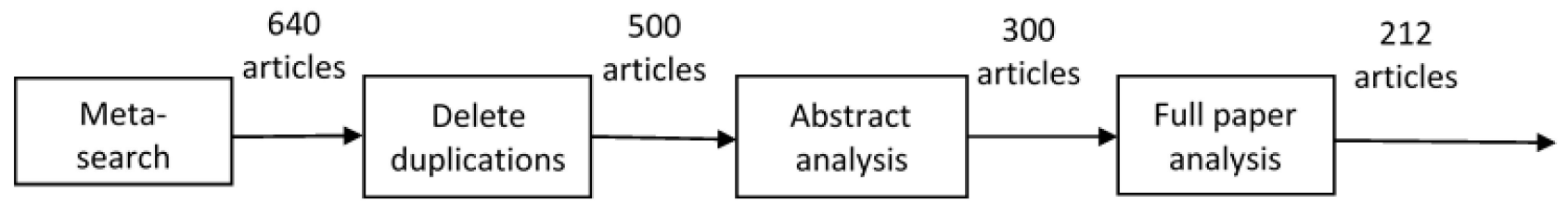

Keywords:

- Pressure: stakeholder pressure, external pressures, institutional pressure.

- Sustainable practices: sustainable practices, green practices, environmental practices, socially oriented practices, corporate social and environmental practices, environmentally friendly practices, Sustainability, corporate citizenship, corporate social responsibility, green purchasing, green logistics.
- Does paper talks the effect of stakeholder pressure on sustainable practices?

- Does it talks about this influence either inside or outside organization?
- Does paper fit to our research question?

Figure 1. Screening methodology adapted from Gimenez and Tachizawa (2012) with their permission.

In the literature there is significant discussion regarding the definition of sustainability and corporate social responsibility (CSR) [33]. Initially, CSR focused more on the social considerations [33], while corporate sustainability (CS) focused on the environmental issues [34]. Other scholars define sustainability from a triple-bottom-line perspective, focusing on the three dimensions, including economic, social, and environmental concerns (e.g., [35]). Though CSR and CS have differences, they coincide due to the focus on both environmental and social concerns. The concept of CSR, that integrates the economic, social, and environmental dimensions, and the triple-bottom-line definition of CS, are alike. Both CSR and CS aim to balance economic performance, environmental and social concerns, and whether they formulize environmental issues as a subgroup of social issues or as the third dimension of sustainability. Given this, we will interchangeably use both terms, CSR and CS, in this study.

Lastly, all the authors read each article and differences in ratings were discussed and confirmed, resulting in consensus ratings for each study. The factors coded from the articles were selected to show evidence in the area of the sustainability focus, theoretical approach, methodology, and the industrial sectors covered. Table 1 provides a summary of the coding rules used in this review. The literature coding led to Table 2, which describes the summary of the literature review categorized in different themes. In the next section, we report on the literature analysis and discuss the opportunities for future research. 
Table 1. Coding rules.

\begin{tabular}{cc}
\hline Coding Group & Description \\
\hline Mediating and moderating variables & $\begin{array}{c}\text { Studies using mediating and moderating variables } \\
\text { were coded as one category, while those without } \\
\text { mediating and moderating variables were coded as } \\
\text { another category. }\end{array}$ \\
Theoretical len(es) & $\begin{array}{c}\text { Studies were coded using one or more theories, and } \\
\text { the interaction of these theories, while developing } \\
\text { their hypotheses and models. The most common } \\
\text { theories included the stakeholder theory, institutional } \\
\text { theory, resource dependence theory, etc. }\end{array}$ \\
& $\begin{array}{c}\text { The methodology included surveys, case studies, } \\
\text { secondary data (empirical), interviews, surveys and } \\
\text { interviews, and others. Studies using only the survey } \\
\text { methodology were coded as a "survey", those using } \\
\text { the case study method were coded as "case studies", } \\
\text { those using only interviews were coded as } \\
\text { "interviews", a combination of surveys and interviews } \\
\text { were coded as "surveys and interviews", and those not } \\
\text { using any of the above methods were coded } \\
\text { as "other". }\end{array}$ \\
\hline Methodology & $\begin{array}{c}\text { Studies were assessed as to whether they targeted the } \\
\text { manufacturing industry or service sector or a } \\
\text { combination of both. }\end{array}$ \\
Sectors covered & $\begin{array}{c}\text { Studies addressing social dimensions, environmental } \\
\text { dimensions, a combination of both, environmental } \\
\text { dimensions, economic dimensions, and the } \\
\text { triple-bottom-line were assessed and coded. }\end{array}$ \\
\hline
\end{tabular}

Table 2. Summary of results: primary dimensions.

\begin{tabular}{ccc}
\hline Themes & Count & \% \\
\hline Mediating and moderating variables & & 62 \\
\hline Studies without mediating and moderating variables & 131 & 15 \\
\hline Studies with mediating variables & 33 & 21 \\
\hline Studies with moderating variables & 44 & 2 \\
\hline Studies with moderating and mediating variables & 4 & 100 \\
\hline Total & 212 & 42 \\
\hline Theoretical lens(es) & 26 \\
\hline Stakeholder theory & 89 & 6 \\
\hline Institutional theory & 56 & 8 \\
\hline Stakeholder theory + institutional theory & 12 & 2 \\
\hline Resource-based view & 16 & 5 \\
\hline Resource dependence theory & 4 & 11 \\
\hline Others & 11 \\
\hline None & 24 & \\
\hline
\end{tabular}


Table 2. Cont.

\begin{tabular}{|c|c|c|}
\hline Themes & Count & $\%$ \\
\hline Total & 212 & 100 \\
\hline \multicolumn{3}{|l|}{ Methodology } \\
\hline Surveys & 152 & 72 \\
\hline Case studies & 18 & 8 \\
\hline Secondary data & 14 & 7 \\
\hline Interviews & 11 & 5 \\
\hline Surveys + interviews & 4 & 2 \\
\hline Other (review + conceptual) & 13 & 6 \\
\hline Total & 212 & 100 \\
\hline \multicolumn{3}{|l|}{ Industrial Sectors } \\
\hline Manufacturing & 150 & 71 \\
\hline Service & 22 & 10 \\
\hline Manufacturing + service & 31 & 15 \\
\hline Other (conceptual + reviews) & 9 & 4 \\
\hline Total & 212 & 100 \\
\hline \multicolumn{3}{|l|}{ Dimensions of Sustainability } \\
\hline Environmental dimension & 111 & 52 \\
\hline Social dimension & 8 & 4 \\
\hline Environmental + social dimension & 54 & 25 \\
\hline Environmental + economic dimension & 23 & 11 \\
\hline Triple-bottom-line & 16 & 8 \\
\hline Total & 212 & 100 \\
\hline
\end{tabular}

\section{Results Analyses and Discussion}

This section describes the findings and discusses the research opportunities concerning themes identified in the literature, as mentioned in Table 2.

\subsection{Mediating and Moderating Variables}

- The State of the Current Literature

Most studies (62\%) reviewed for this study have addressed the direct effects of stakeholder pressures on the adoption of sustainable management practices. Twenty-one percent of studies used moderating variables, $15 \%$ of articles used mediating variables, and only $2 \%$ of studies used both mediating and moderating variables. The above-mentioned allocations of mediating and moderating variables in the articles reviewed for this study are shown in Figure 2.

\section{- $\quad$ Mediating Variables}

Out of the total studies, $15 \%$ included mediating variables, such as: top management support [36], environmental and social reputation [37], resource commitment [38], climate sensitivity [39], innovative capabilities [40], managerial perceptions [41], green product/process innovations [42], a proactive environmental strategy [2] (Graham et al., 2020), perceived benefits, ethical leadership, sustainability capability (resources + knowledge) [43], primary stakeholders [44], size [45], environmental stewardship behaviors (ESB) of managers [46], internal green supply chain management (GSCM) practices [15], attitudes towards environmental issues, perceptions about stakeholder issues, perceptions of 
control [47], support from organizations and stakeholder pressures between social expectations and environmental practice adoptions [5], training [13], a corporate CSR-oriented culture [48], the potential mediating role of supplier performance in the operational and supply chain of the focal company, top management commitment [49], innovative capabilities that include exploratory and exploitative capabilities [40], resources and knowledge [43], customer loyalty, organizational culture, flexible design, product diversity, and quality orientation [50].

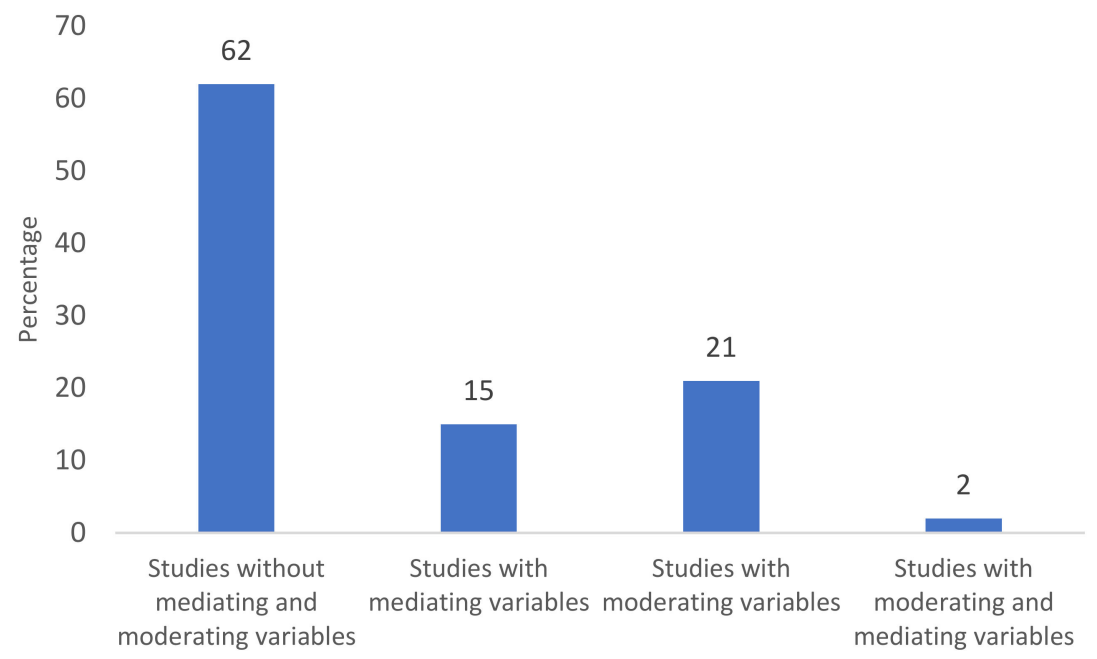

Figure 2. Mediating and moderating variables in articles reviewed.

- Moderating Variables

Out of the total studies, $21 \%$ of studies incorporated moderating variables, such as visibility, top management support, the organizational structure, managerial support [51] (Jazairy and Haartman, 2020), resource availability [36], managerial autonomy [52], an integrated strategy, continuous improvement, a lack of financial resources, a lack of time, a lack of knowledge, risk associated with sustainable practice adoptions [53], slack resources [54], perceived benefits or top management support [55], environmental commitment, resource availability [55], organizational culture (a flexible orientation (development-oriented) and a control orientation (rational and hierarchical) [56], corporate profitability [57], industry types [58], size [59-61], community pressure [62], cultural environment [63], environmental awareness among managers, internationalization, the industrial sector [64], dependence on partners, trust in partners, thedurability of relationships with supply chain partners, top management commitment, the implementation of quality management, employee training and education [57], local community and*consumers [65], complexity of service [66] the company experience concerning sustainability, market situations, dynamic industries, static industries [67], supply chain integration [14], organizational slack resources, asset specificity [68], the expectation of a competitive advantage [69], the business subsector (to differentiate activities with specific risks concerning environmental issues, human rights, or labor rights), the country of origin, and the company's position in the supply chain [70], countries (such as Denmark, Germany, and the Netherlands [71], organizational culture (flexibility-oriented, control-orientation) [72], dynamic capabilities (knowledge assessing, co-development, supply chain partner development, supply chain rebuilding, and flexibility) [73], internal sustainability team power, and external powers from buyers [74].

In summary, in the earlier mentioned studies, organizational level/firm level factors were widely addressed as moderating variables, followed by the individual level and macro level factors. Identifying further potential moderating variables at the individual level, organizational level, and the macro level is important for theory and practice. There is a need for more research to identify the potential moderating variables sorrounding the link between stakeholder pressure and the adoption of sustainable management practices. 


\section{- $\quad$ Further Actions}

The role of contextual variables is crucial because they enable organizations to practice the appropriate sustainable management practices, which are beneficial to the organizations [75]. Meixell and Luoma [17] called for the investigation of the association between stakeholder pressure and the adoption/implementation of sustainable management practices under different contexts. Researchers, including Hartmann et al. [76] and Yu and Choi [48], called for identifying other potential mediating/moderating variables and testing their impacts empirically. Establishing a link between stakeholder pressure and sustainable practices can provide a relevant contribution. However, as the boundary conditions underlying the relationship between stakeholder pressure and sustainability practices remain unclear, there is a greater need for studying the contextual variables as moderating variables in these relationships, to have an in-depth and contextual understanding. In answering the question, "under what conditions do stakeholder pressures influence the adoption of sustainable practices?", this study suggests the following potential moderating variables.

Appendix B shows a model that depicts the potential moderating variables. Among the suggested variables, management commitment [54], the environmental strategy, coordination, and the comprehensiveness of the environmental management system are crucial for driving environmentally friendly behaviors [55,77-79] and can possibly act as moderating variables. In addition, plant and firm characteristics, including historical environmental performance, the competitive position of the parent company, the organizational structure of the plant [80], the learning orientation of a firm [76,81], and the leadership types [82] can potentially moderate the relationship between external pressure from stakeholders and the adoption of sustainable management practices. Internal capabilities and resources could provide insights into the antecedents of sustainable practice adoption [45] and could possibly play a moderating role. The adoption of advanced technology, collaborating with customers and suppliers and their innovative abilities, in addition to their known strategic benefits, may endow companies with capabilities that help them address environmental challenges and experiences that concern the collaboration with stakeholders [83], which could act as potential moderators.

Though the extant literature mostly explores how financial performance relates to social and environmental responsibilities, other aspects of performance, namely, the market share and the product development introductions, could also be important. Therefore, financial success, compared to innovation success or market share success, influences the investment in sustainable management practices and could act as moderating variables [62] In addition, environmental uncertainty, competitive intensity [84], and enablers including integrated strategy, continuous improvement, stakeholder engagement, and streamlining processes [53] can influence the association between stakeholder pressure and the adoption/implementation of sustainable management practices. Furthermore, dynamic capabilities, including integrative strategies (green products, biodiversity, organic processes, and self-sufficient electricity), sustainability culture (a sustainable mindset, environmental awareness, learning orientations, and decision-making processes), and organizational routines for innovation (new green processes and products, partnerships/alliances, and knowledge management) [85] can be used as moderating variables.

At the individual level, mood, personality, values, the level of education, religion, and culture might change managers' perceptions and could influence the way environmental elements are assessed [47], possibly acting as moderating variables. The inclusion of macrolevel contextual variables may also produce useful results. For instance, environmental uncertainty [84], environmental dynamism, the industry structure [86], governance [87], GDP per capita, economic freedom, income inequality, corruption, and political and civil freedoms $[35,88]$ could influence the adoption of sustainable practices and should, therefore, be treated as moderating variables in future studies.

In summary, regarding the conditions under which stakeholder pressure influences the adoption of sustainable management practices, more research is needed on sustainability at different levels, including institutional (macro-level), organizational, and individual 
levels [89]. Given the current literature review, organizational-level factors are widely addressed, followed by macro-level factors, and finallym the individual-level factors. Thus, there is more research on organizational factors compared to the macro-level and the individual-level factors. There is less research on the personal (individual)-level factors than organizational and macro-level factors; therefore, more research should be devoted to the individual-level factors and macro-level factors. A real external perspective on sustainability, which focuses only on the external institutional environment, considers the company as a black box, while an internal approach, focusing on the organizational level and individual level sustainabilities recognize companies as an isolated island [82]. Therefore, investigating the moderating effects of variables, as mentioned earlier, consisting of both internal, namely, organizational- and individual-level factors and the external environment (macro-level factors) is needed to provide a realistic picture of the links between stakeholder pressure and the adoption of sustainable management practices. In addition, as found by Banerjee et al. [90], firm-level factors contribute a greater variation to environmental outcomes than the country-level factors, but in combination they contribute a greater variation in the environmental outcomes. The interaction between firm-level (the individual and organizational levels) and country-level factors, as moderating variables (as suggested above), should be investigated so as to have an in-depth and realistic understanding about the relationship between stakeholder pressure and sustainable practice adoption. This discussion leads to the following future research opportunity (ROP):

ROP1: Studies should investigate the moderating effects of the above-mentioned individual-level, organizational-level, and macro-level factors, and their interactions in the link between stakeholder pressure and the adoption of sustainable management practices.

\subsection{Theoretical Lens(es)}

\section{- The State of the Current Literature}

The literature reviewed for this study used various theories, including the stakeholder theory $(42 \%)$, the institutional theory $(26 \%)$, the combined stakeholder and institutional theory $(6 \%)$, the resource-based view $(8 \%)$, the resource dependence theory $(2 \%)$, and others (5\%), including the legitimacy theory, contingency theory, theory of reasoned action (TRA), and stewardship theory to show the influence of external stakeholder pressure on the adoption of sustainable management practices. In contrast, $11 \%$ of studies did not base their research on any established theory. Figure 3 shows the distribution of theoretical lenses in articles reviewed for this study.

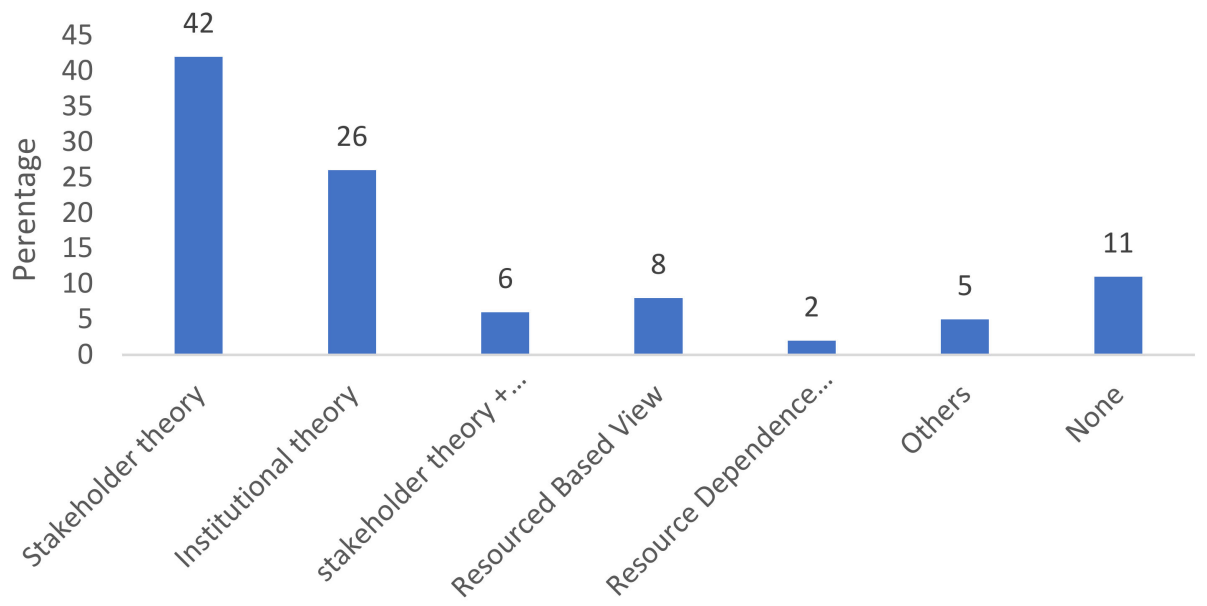

Figure 3. Theoretical lenses in article reviewed.

The stakeholder theory only talks about actors (stakeholders) and the institutional theory mentions where these actors are located. Institutions shape the large-scale reward structures and sources of trust and legitimacy [91]. Stakeholders can act as mediators 
to enhance or buffer the institutional forces (coercive, mimetic, and normative). While the institutional theory does not explicitly develop the idea of stakeholders as actors, the stakeholder theory does not adequately promote institutions, which develop from the varied stakeholders' interests. Within each pillar of the institutional theory, actors can further categorize motivations. Not all stakeholders exist within one pillar. For instance, shareholders may not be directly included in cultural-cognitive pillar motivations, and public stakeholders may not have a direct role within the regulations. New stakeholders can emerge, even though they were not present earlier [92]. Furthermore, stakeholders can move from one pillar to another to gain their goals, or engage with other stakeholders, who have a direct role within each pillar. For example, public stakeholders can create institutions around their interests that do not directly lead to firm behavioral change, but that does catch the attention of regulatory stakeholders (ibid). Institutions give power and legitimacy, and the institutions are often realized via stakeholder mechanisms [54]. When stakeholders' demands for improving social/environmental performance have gained sufficient legitimacy from the institutional environment, firms will have limited option to decide if, and how, to respond to their requests.

Some studies (4\%) based their research on the resource dependence theory (RDT). While the stakeholder theory relates to identifying different groups, the RDT focus on how stakeholders achieve their aim. The resource dependence theory suggests two dimensions that classify stakeholder influence strategies. On the one hand, stakeholders can either withdraw resources (withholding strategy) or put usage conditions on their supply (usage strategy) to influence firm behavior. On the other hand, stakeholders can either manipulate the flow of resources to the firms themselves (direct strategy) or work through an ally that handles the manipulation (indirect strategies).

The resource-based view, which addresses the firm's ability to adopt sustainable management practices, resulting from the firm's internal capabilities, is also used ( $8 \%$ ) in research studies. The firm could respond to stakeholder demands, which gives access to resources [93]. For instance, a collaboration with suppliers can improve a firm's ability to adopt sustainable practices [94,95]. Hart [96] suggested that stakeholder integration could be a capability resulting from product stewardship that needs the integration of the key external stakeholders [93].

Out of the other theories (5\%), some studies have jointly used the legitimacy theory with the stakeholder theory. Legitimacy has been defined as a "generalized perception or assumption that the actions of an entity are desirable, proper, or appropriate within some socially-constructed system of norms, values, beliefs, and definitions" ([97], p. 574). Legitimacy shows a reaction of social groups, given a perceived matching between organizational behaviors and the norms of acceptable behaviors shared by these groups [98]. Legitimacy is a state of being that is suitable to the appropriate laws, rules, and social values $[99,100]$. Organizations that act according to the rules and regulations of their context can be defined as legitimate organizations [101]. The presence of a contract between a business and society [98] expresses that the company is committed to socially desirable actions. Any violation of this agreement reduces the legitimacy and, consequently, the existence of a firm [91,102].

Among other theories, the contingency theory has been used with the institutional theory in studies that included conditional/moderating variables on the relationship between institutional pressures and the adoption/implementation of sustainable practices. The contingency theory shows the external environment that surrounds the organization and influences its internal environment. Research addressing the moderating variables of the link between institutional pressures and the implementation of sustainable practices can develop a theoretical model by integrating institutional and contingency theories [56].

The stewardship theory has also been jointly used with the institutional theory. According to Scott [103], the level of institutional pressure asserted on firms relies on the understanding and manipulation of the actors/stakeholders. The stewardship theory provides another perspective, where actors within an organization seek long-term bene- 
fits from socially responsible behaviors, rather than selfish behaviors, which are mostly short-term. The social stewardship theory argues that social stewards, for instance, managers and principals, tend to enhance their personal and organizational interests while reducing harmful social effects [104]. Stewardship includes taking care of, and preserving, resources [105]. Behaviors concerning stewardship assume that the actors of a firm take responsibility and accountability for the effect of their organizational actions [106].

Some studies have based their research on the stakeholder theory with the theory of reasoned action (TRA) for studying the motivations for environmentally-related decisionmaking [107]. The TRA consists of two primary constructs, attitudes and subjective norms [108]. A person's attitude toward a behavior is personal and relates to their positive or negative evaluation of acting. The primary driver of this social pressure is termed "subjective norms" (ibid). Subjective norms are often operationalized by asking respondents to indicate whether "important others" would approve or disapprove a particular behavior [109].

\section{- $\quad$ Further Actions}

As mentioned earlier, the stakeholder theory is the prominent theory used in the literature, followed by the institutional theory. However, a few researches have jointly used the stakeholder and institutional theories to explain how the stakeholder pressures influence the firms' adoption of sustainable management practices. This conjunction is very crucial, as the stakeholder theory and the institutional theory are not enough to explain the influence of stakeholders' forces on the adoption of sustainable practices. Institutions provide legitimacy and power to stakeholders, and institutions are often realized via stakeholder mechanisms. When stakeholders' demands for improving social/environmental performance have gained sufficient legitimacy from the institutional environment, firms will have the option to decide if, and how, to respond to their requests. Therefore, both the stakeholder and institutional theories need to be used jointly in studies that investigate the impact of stakeholder pressure on the adoption of sustainable management practices.

While the legitimacy theory addresses the expectations of society in general, the stakeholder theory focuses upon the expectations of a particular group. As the general expectations of a society shape the expectations of particular groups, future studies should jointly consider providing more in-depth explanations on the adoption of corporate social and environmental practices, given stakeholder pressure. Studies should aim to address how stakeholders achieve their aims using the resource dependence theory (RDT), jointly with the stakeholder theory, which categorizes actors into different types. Research addressing moderating variables on the relationship between institutional pressures and the implementation of sustainable practices can develop a theoretical model by integrating the contingency theory with both institutional and stakeholder theories. According to Scott (2014), the degree of institutional pressure asserted on firms depends on the understanding and manipulation of actors/stakeholders. The stewardship theory provides another perspective, where actors within an organization seek long-term benefits from socially responsible behaviors, rather than selfish and short-term behaviors [110]. Thus, the stewardship theory could be used together with the institutional theory, where internal stakeholders opt for long-term objectives and act in a socially responsible way, rather adopting short-term opportunistic behaviors. The theory of reasoned action (TRA) should be used, where researchers aim to investigate the influence of stakeholder attitudes and subjective norms on the adoption of sustainable management practices. Finally, the resource based view (RBV) and the resource dependence theory (RDT) can be integrated to investigate the influence of firm capabilities, such as supplier cooperation on sustainability practice implementation. This discussion leads to the following research opportunity:

ROP2: Researchers should jointly use the stakeholder and institutional theories, along with the other theories (as mentioned above), to investigate the link between stakeholder pressure and sustainability practices. 


\subsection{Methodology}

- The State of the Current Literature

The studies that were reviewed for this research used survey data $(72 \%)$, case studies $(8 \%)$, secondary data $(7 \%)$, interviews $(5 \%)$, surveys and case studies $(2 \%)$, and others (reviews and conceptual studies) (6\%). The allocation of these methods are shown in Figure 4 .

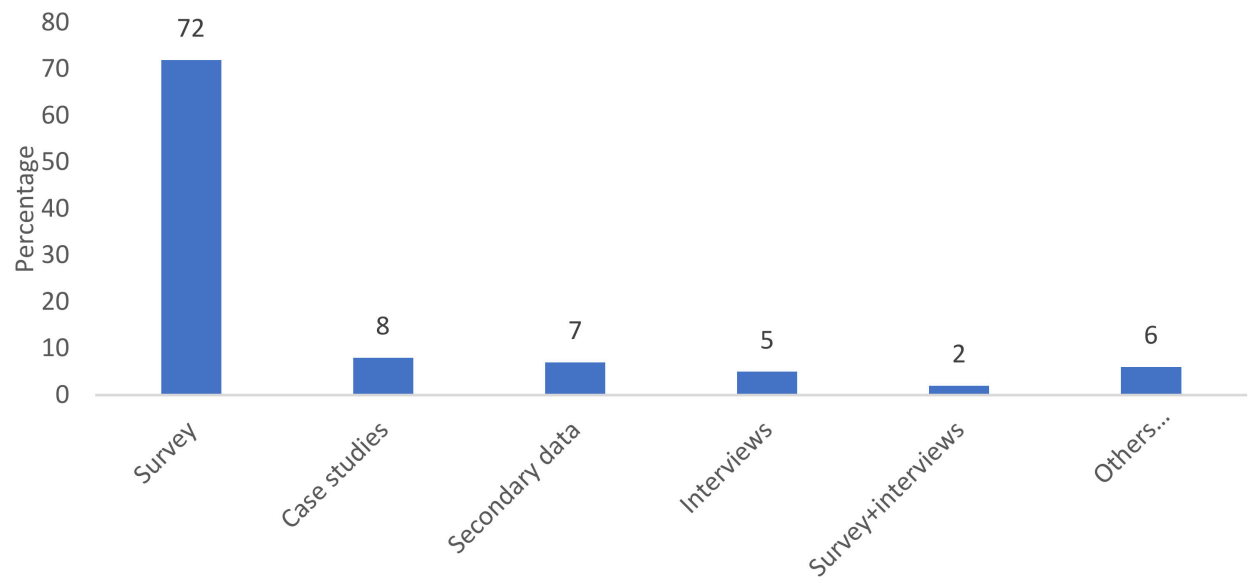

Figure 4. Methods used in articles reviewed.

\section{- Further Actions}

The survey method was the most dominant methodology, followed by case studies, and secondary data in the reviewed research. Though a survey method provides a general overview about the influence of stakeholder pressure on the adoption of sustainable management practices, case studies provide a more in-depth understanding on the above relationship. Secondary data, on the other hand, provides an objective measurement of the sustainable management practices and stakeholder pressure constructs. As the case study method is less researched than the survey method, more studies that use case study methodology are needed to explain, in detail, the influence of pressure on the adoption of sustainable management practices. Studies that use more than one method are underrepresented. The various methods have their merits and demerits. To validate the findings from the use of one method, a combination of different methods, such as surveys and case studies, should be used in further studies. This leads to the following research opportunity:

ROP3: Further research could use the survey method and a combination of survey and case study methods to provide insight into the link between stakeholder pressure and sustainability practices.

\subsection{Industrial Sectors}

- The State of the Current Literature

Out of the total studies, $71 \%$ addressed the manufacturing sector, $10 \%$ the service sector, $15 \%$ the service and manufacturing sector combined, and $4 \%$ consisted of other studies which were either conceptual or were reviews. The illustration of the various sectors covered in the reviewed articles for this study is shown in Figure 5.

\section{- $\quad$ Further Actions}

The manufacturing sector, which has a visible environmental and social impact [111,112] is widely researched compared to the service sector. Unlike the manufacturing sector, the service sector includes a more varied collection of economic activities with less visible impacts on the environment and society. In addition, services vary from goods in four main characteristics: (1) intangibility, where service outputs cannot be seen and touched; (2) the simultaneity of production and consumption, where service outputs are consumed as they 
are produced; (3) heterogeneity, where service outputs vary immensely, and (4) perishability, where service outputs cannot be stored. Keeping all these factors in mind, it is more difficult and challenging to assess the environmental and social impacts of the service sector [113].

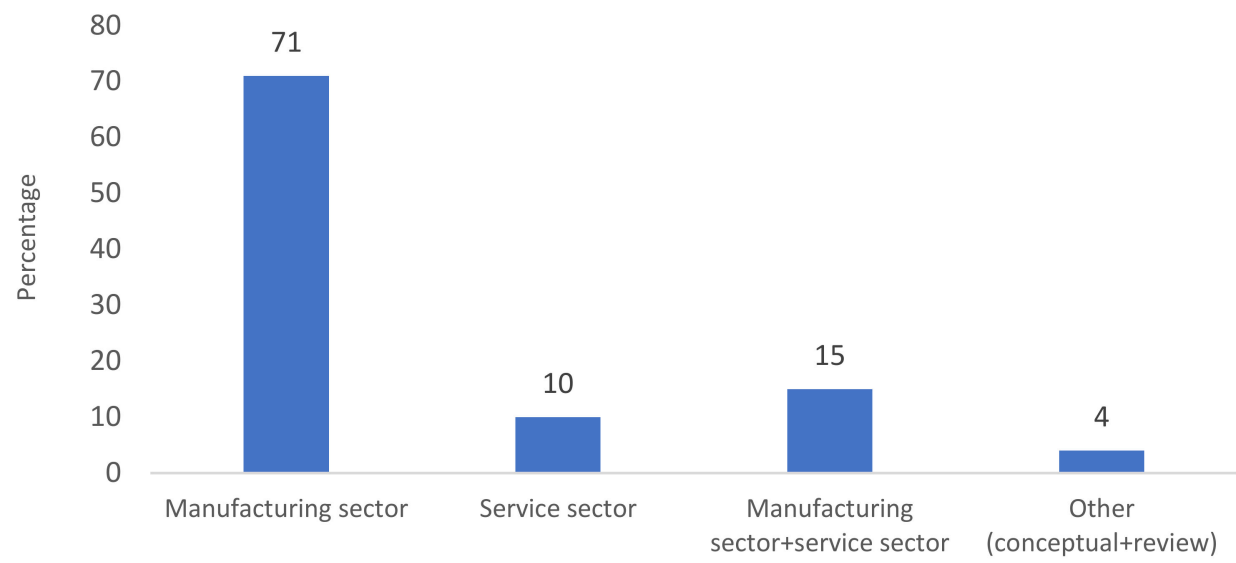

Figure 5. Industrial sectors covered in the articles reviewed.

Despite the essential role of the service sector, questions concerning its sustainability have not been adequately addressed [113,114]. Providing an insight to the sources of competitive advantages of service firms is a vital area for empirical research [115]. How service firms can gain a competitive advantage by embedding environmental and social sustainability has not yet been subject to investigation extensively. Therefore, to fill this gap in the knowledge, studies should investigate the influence of stakeholder pressure on the adoption of environmental and socially sustainable practices in service sectors [76,116,117]. Finally, many researches addressed the high polluting industries, while industries with minimal environmental impacts were less researched. Investigating industries with minimal impact is important to understanding how companies react to the pressure from stakeholders in these industries. Future research should also look at industries with a significant impact, in comparison to those with a minimal societal impact [34]. Comparative studies that investigated the effect of stakeholder pressure on the adoption of sustainable management practices in manufacturing sectors, compared to the service sectors, were not addressed. This comparison will help to determine the pattern of sustainable management practice adoption in the service sector versus the manufacturing sector, given stakeholder pressure. Therefore, studies should investigate the influence of pressure on sustainable management practices in service sectors compared to manufacturing sectors. We suggest the following research opportunity:

ROP4: Further studies need to explore the influence of stakeholder pressure on sustainability practices in the service sector and conduct comparative studies between the service and manufacturing sectors.

\subsection{Dimensions of Sustainability}

\section{- The State of the Current Literature}

The research articles reviewed in this study focus more on the environmental aspect of sustainability, followed by the environmental and social dimensions, the environmental and economic dimensions, the triple-bottom-line, and finally, the social aspect. This has been illustrated in the fact that out of the total studies reviewed for this study, $52 \%$ reported only the environmental dimension, 25\% reported the environmental and social dimensions, $11 \%$ reported the environmental and economic dimensions, $8 \%$ reported the triple-bottom-line, and only $4 \%$ reported the social aspect. These dimensions of sustainability are depicted in Figure 6. 


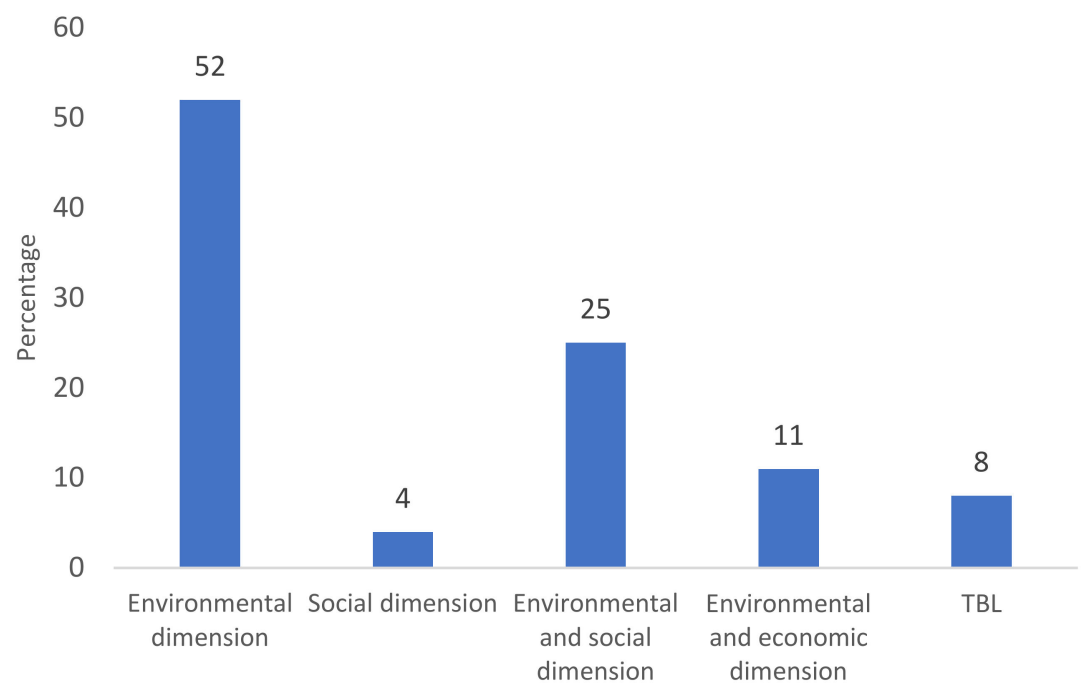

Figure 6. Sustainability dimensions covered in the articles reviewed.

\section{- $\quad$ Further Actions}

A larger emphasis on the environmental dimension, than on the social dimension, derives from the assumption that the environmental dimension is perceived, by managers, as being more strategic in terms of the economic efficiency, provided that social activities could affect (at least in the short-term) cost performance $[4,118]$. Moreover, the environmental factor is more noticeable, simpler to quantify, and similar to the environmental laws [119]. Although the social context is intangible, mostly inside corporations, it encompasses numerous topics which are impossible to quantify and, as a result of these aspects, firms cannot deal with these issues properly. Despite these challenges, the social component of sustainability is acknowledged but it has gained less emphasis than anticipated. The existence of social problems will affect brand reputations and firm financial results. Keeping this in mind, several researchers (e.g., $[117,120]$ ) suggested that more research is needed regarding the social dimension of sustainability.

The social and environmental aspects are both discussed separately, and there is little insight into how the two dimensions should be combined [31]. There are trade-offs between these two scales, and a certain amount of time synergy can also be derived by their mutual consideration. As a result, further research should examine the social, as well as the environmental and social, aspects of interactions for more awareness in this field.

Finally, the interaction between the environmental, social, and economic dimensions (called the triple-bottom-line) is less covered. This interaction offers better knowledge on the trade-offs, as well as on the synergy, between individual dimensions and provides a complete understanding of sustainability. Thus, there is need for researches to investigate all the three dimensions of sustainability, rather than only targeting the individual dimensions in both manufacturing and service sectors. We present the following research opportunity:

ROP5: More research is needed, particularly on the social dimension, as well as jointly on the social and environmental dimensions and on environmental, social, and economic dimensions of sustainability.

\section{Conclusions and Research Limitations}

Stakeholders are increasingly pressing companies to integrate environmental and social issues into their business operations due to the detrimental impacts of globalization, such as environmental and social problems, among others. This study reviewed the literature on the effect of stakeholder pressure (external to the firm) on the implementation of sustainable management practices. We used dimensions, such as mediating and moderating factors, theoretical lenses, sustainability dimensions, manufacturing industries, and methods to frame the literature and gain insight into how demand from stakeholders 
affects the implementation of sustainable management practices. Empirical proof of the relationship between stakeholder pressure and sustainable management practices is mixed: stakeholder pressure often promotes sustainable practices, sometimes has little impact, and sometimes discourages sustainability practices. The rich context for further studies is whether, and when, companies adopt make improvements due to stakeholder pressure. This paper provides a collection of conceptual resources and future research opportunities arising from a thorough overview of the literature examined.

The fundamental finding of this study is that research discussing the direct impact of stakeholder pressure on sustainable management practices predominates over those with mediating and moderating variables. The majority of studies that incorporated mediating and moderating variables in their studies addressed the organizational level, followed by macro-level considerations, as moderating variables. This paper presents a model (Appendix B), which suggests further researchers to test the proposed individual-level variables, as well as the organizational-level and macro-level factors, and the interaction of individual-, organizational-, and macro-level factors as moderating variables. This will help to further contextualize the link between stakeholder pressure and the adoption of sustainable management practices. Second, the most dominant theoretical lenses are the stakeholder theory and the institutional theory. Further research should jointly use these theories to analyze the effect of stakeholder pressure on the implementation of sustainable management practices. Third, the manufacturing sector is more frequently covered than the service sector. Further studies can address the service sector, and the comparison between the manufacturing and service sectors. Fourth, survey methodology is widely addressed; potential case studies need to be undertaken in order to provide an in-depth perspective into the connection between stakeholder pressure and sustainable management practices. Fifth, the environmental dimension of sustainability is more addressed, compared to the social dimension. Future studies could investigate the social dimension and the interaction of the social and environmental dimensions of sustainability.

Overall, this systematic review offered insight into the effect of stakeholder pressure on sustainable management practices and established a range of directions for future research. Recognizing the complexity of a firm's response to stakeholder pressure, in terms the of sustainable management practices, is an important milestone, along with the congruence between stakeholder pressure and a sustainability focus. This analysis of the effects of stakeholder pressure on sustainability practices allows for a better scholarly understanding of the topic. The literature review of Meixell and Louma (2015) suggested identifying the boundary conditions surrounding the link between stakeholder pressure and the adoption of sustainable management practices.

This study advances literature on the relationship between stakeholder pressure that comes from outside the firm, as well as the adoption of sustainable management practices by developing a model (Appendix B) which shows the influence of the potential organizational, individual-, and macro-level factors, and their interactions, on the above relationship. Furthermore, this study presents other future research directions for further research.

This research suffers from the following limitations in spite of its contribution. First, the selected key terms were chosen with due consideration, but this option may be another disadvantage of this research. Under other marks, articles containing relevant information about the subject might appear. Second, this research overlooked ongoing articles, $\mathrm{PhD}$ theses, conference papers, textbooks, and papers outside the databases listed in the methodology section. These sources may provide specific information related to the subject. Finally, while the papers were evaluated according to the above methodology by several scholars, the collection of the papers could be considered subjective. 


\begin{abstract}
Author Contributions: Conceptualization, F.H., S.F. and B.V.W.; methodology, F.H., S.F., B.V.W. and Y.C.; software, F.H.; formal anlaysis, F.H.; investigation, F.H. and S.F.; resources, B.V.W.; writing-original draft preparation, F.H.; writing-review and editing, F.H., S.F., B.V.W. and Y.C.; visualization, F.H.; supervision, S.F.; project administration, F.H. All authors have read and agreed to the published version of the manuscript.
\end{abstract}

Funding: The research received no external fundings.

Institutional Review Board Statement: Not applicable.

Informed Consent Statement: Not applicable.

Data Availability Statement: Data is available on request from the authors.

Conflicts of Interest: The authors declare no conflict of interest.

\title{
Appendix A
}

This appendix shows distribution of the articles reviewed for this study in different journals.

Table A1. List of articles in different journals.

\begin{tabular}{cc}
\hline Authors & Avenue/Journal \\
\hline $\begin{array}{c}\text { Ouyang et al. (2020); Testa et al. (2015); } \\
\text { Nguyen and Adomako (2021) }\end{array}$ & $\begin{array}{c}\text { Corporate Social Responsibility and } \\
\text { Environmental Management }\end{array}$
\end{tabular}

Daddi et al. (2021); Baah et al. (2020) [37]; de Oliveira et al.

(2019); Bamgbade et al. (2019); Caldera et al. (2019);

Sureeyatanapas et al. (2018); He et al. (2018); Aboelmaged

(2018); Li and Ramanathan (2018); Li et al. (2017); Ahmad et al.

(2017); Kudlak (2017); Vanalle et al. (2017); Betts et al. (2018);

Haleem et al. (2017); Damert et al. (2017); Vilchez et al. (2017);

Miras-Rodríguez et al. (2017); Shnayder et al. (2016); X et al.

Journal of Cleaner Production

(2016); Orsato et al. (2015); Galiazzo and klassen (2015);

Betts et al. (2015); Lu and Abeysekera (2014); Singh et al. (2014);

Valiente et al. (2012); Neugebauer (2012); Qi et al. (2011);

Massoud et al. (2010); SambasIvan and Fei (2008); Zheng (2005); Hillary (2004)

\begin{tabular}{cc}
\hline Aggarwal and Jhe (2019) & Journal of Strategy and Management \\
\hline Jakhar et al. (2020); Kowalczyk and Kucharska (2020); Qiu et al. & \\
(2020); Seroka-Stolka and Fijorek (2020); Jiao et al. (2020); & \\
Konadu et al. (2020); Song et al. (2020); Gao et al. (2019); & \\
Wijethilake and Lama (2018); Yen (2018); Wang et al. (2018); & Business Strategy and the Environment \\
Shubham et al. (2018); Littlewood et al. (2018); Cadez et al. & \\
(2018); Choi and Kim (2018); Garrone et al. (2018); Li et al. & \\
(2018); Singh et al. (2017); Yu et al. (2017); Tsai et al. (2017); & \\
Hyatt and Berente (2017); Wu (2015); Böttcher and Müller (2015); & \\
Ervin et al. (2015); Sajjad et al. (2015); Castka and Prajogo (2013); Brammer et al. (2012); Hofmann et al. (2012); & \\
González-Benito and González-Benito (2010); Delmas and & \\
\hline
\end{tabular}

Li et al. (2019); Choi et al. (2019); Liu (2018); Crotty and Rodger (2012); Zhu et al. (2008); Cantele and Zardini (2020); Lozano and Hartmann (2018); Boiral et al. (2017); Lee et al. (2017); Kim and Kim (2016); Lozano et al. (2015); Lozano (2013); Eweje (2011);

Corporate Social Responsibility and
Environmental Management

Babiak and Trendafilova (2011); Nawrocka (2008)
Gong et al. (2019); Mani and Gunasekaran (2018); Xiao et al. (2018); Azadegan et al. (2018); Dubey et al. (2017)
International Journal of Production Economics 
Table A1. Cont.

\begin{tabular}{|c|c|}
\hline Authors & Avenue/Journal \\
\hline Chu et al. (2019); Chen et al. (2016); Cantor et al. (2014) & The International Journal of Logistics Management \\
\hline Tatoglu et al. (2019); Tang and Tang (2018) & British Journal of Management \\
\hline $\begin{array}{c}\text { Dubey et al. (2019); Jakhar et al. (2019); Qi et al. (2013); } \\
\text { Garce's-Ayerbe et al. (2012) }\end{array}$ & Management Decision \\
\hline Danese et al. (2019); Shi et al. (2018); Yu and Ramanathan (2015) & International Journal of Production Research \\
\hline Raza et al. (2019) & Journal of Public Affairs. \\
\hline Borini et al. (2019) & Transnational Corporations Review \\
\hline Gunarathne and Lee (2018) & $\begin{array}{l}\text { Management of Environmental Quality: An } \\
\text { International Journal }\end{array}$ \\
\hline Ali et al. (2019) & Sustainability \\
\hline Dou et al. (2018); Sancha et al. (2015) & Journal of Purchasing and Supply Chain Management \\
\hline Mathivathanan et al. (2018) & Resources, Conservation and Recycling \\
\hline Ouyang et al. (2018) & International Journal of Hospitality Management \\
\hline Zhan et al. (2018) & International Journal of Computer Integrated Manufacturing \\
\hline Agi and Nishant (2017); Phan and Baird (2015) & Journal of Environmental Management \\
\hline Huq (2016); Sarkis et al. (2010) & Journal of Operations Management \\
\hline Yu and Choi (2016) & The Social Science Journal \\
\hline Abreu et al. (2015); Vashchenko (2017) & Business Ethics: A European Review \\
\hline Huang et al. (2015) & Journal of Manufacturing Technology Management \\
\hline Zhang et al. (2015) & Journal of Environmental Psychology \\
\hline Liu et al. (2015) & Management and Organization Review \\
\hline Tian et al. (2015) & Journal of Management and Organization \\
\hline
\end{tabular}

Dupire and Zali (2018); Lee et al. (2018); Schaltenbrand et al.

(2016); van Halderen et al. (2016); Pinzone et al. (2015);

Walker et al. (2014); Pedersen and Gwozdz (2014); Allet (2014);

Udayasankar (2008);Sen and Cowley (2013); Caprar et al. (2012);

Perez-Batres et al. (2012); Tsoi (2010); Yang and Rivers (2009)

Adebanjo et al. (2016); Hartmann et al. (2015); Hsu et al. (2013)

Journal of Business Ethics

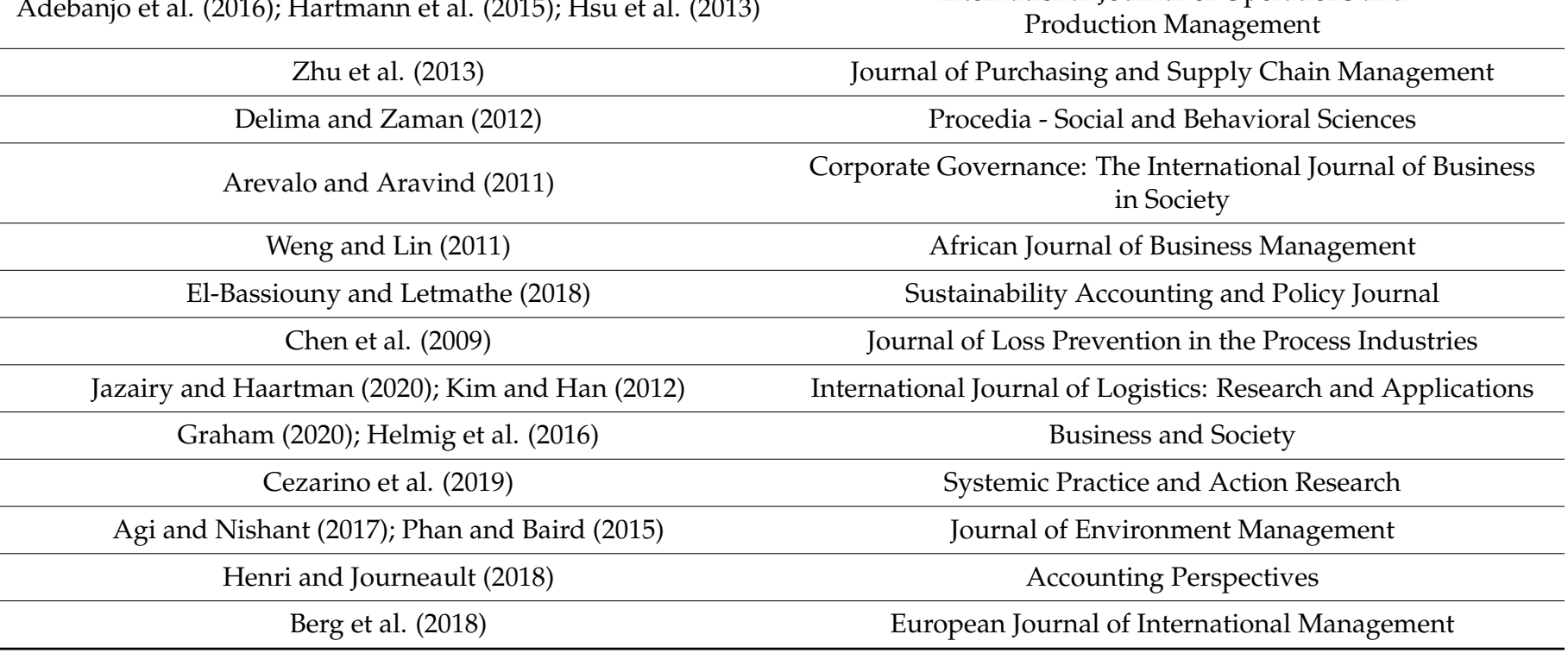


Table A1. Cont.

\section{Authors}

Carrillo-Higueras et al. (2018); Chowdhury et al. (2018)

kawai et al. (2018)

Kim et al. (2018)

Parviainen et al. (2018)

Erdiaw-Kwasie (2018)

Taghian et al. (2015) [121]

Schmitz et al. (2017)

Müller et al. (2017)

Yuen et al. (2017); Dai et al. (2014)

Ashton et al. (2017)

Mass et al. (2017)

Sánchez et al. (2017)

Costa-Campi et al. (2017)

Maggioni and Santangio (2017); Wagner (2015)

Wagner (2011)

Vivores (2017)

Hauser (2016)

Shevchenko et al. (2016); Darnall et al. (2010)

Ahmad (2016)

Rathert (2016); Lewis and Cassells (2010)

Park and Ghauri (2015); Marshall et al. (2010)

Liesen et al. (2015)

Gauerci et al. (2015)

Foerstl et al. (2015); Reuter et al. (2010)

Schoenherr et al. (2014)

Palsson and Kovacs (2014); Tate et al. (2014)

Berrone et al. (2013)

Ayuso et al. (2013) [70]; Ashby et al. (2012); Lee (2008)

Surroca et al. (2013); Henriques and Sadorsky (1999)

Cagno and Triani (2013)

Kim and Lee (2012)

Zyglidopoulos et al. (2012)

López-Gamero et al. (2011)

Camison (2010); Baden et al. (2009)

Campbell (2007)

Campbell (2006)

Jorgensen and Knudsen (2006)

Henriques and Sadorsky (1996)

Yang et al. (2021)

Yunus et al. (2020)
Avenue/Journal

Australian Journal of Environmental Management Inernational Business Review

Journal of Business Review

WMU Journal of Maritime Affairs

Social Responsibility Journal

Organization and Environment

Journal of Public Policy and Marketing

Transportation Research Part E

Journal of Environmental Planning and Management

Journal of Business Economics

The International Journal of Logistic Management Energy Policy

Ecological Economics

Resources Policy

International Journal of Energy Sector Management

Journal of Management Studies

Research policy

Journal of International Business Studies

Journal of World Business

Accounting, Auditing, and Accountability Journal

The international Journal of Human Resource Management

Journal of Supply Chain Management

Business Logistics

International Journal of Physical Distribution and Logistics Management

Strategic Management Journal

Supply Chain Management: An International Journal

Academy of Management Journal

Applied Energy

The International Journal of Logistics Management Journal of Business Research

Cornell Hospitality Quarterly

European Management Journal

Academy of Management Review

American Behavioral Scientist

The International Journal of Business in Society

Journal of Environmental Economics and Management

Benchmarking: An International Journal

Sustainability Accounting Management and Policy Journal 


\section{Appendix B}

This appendix presents the model, which shows the potential moderating variables on the relationship between stakeholder pressure and the adoption of sustainable management practices.

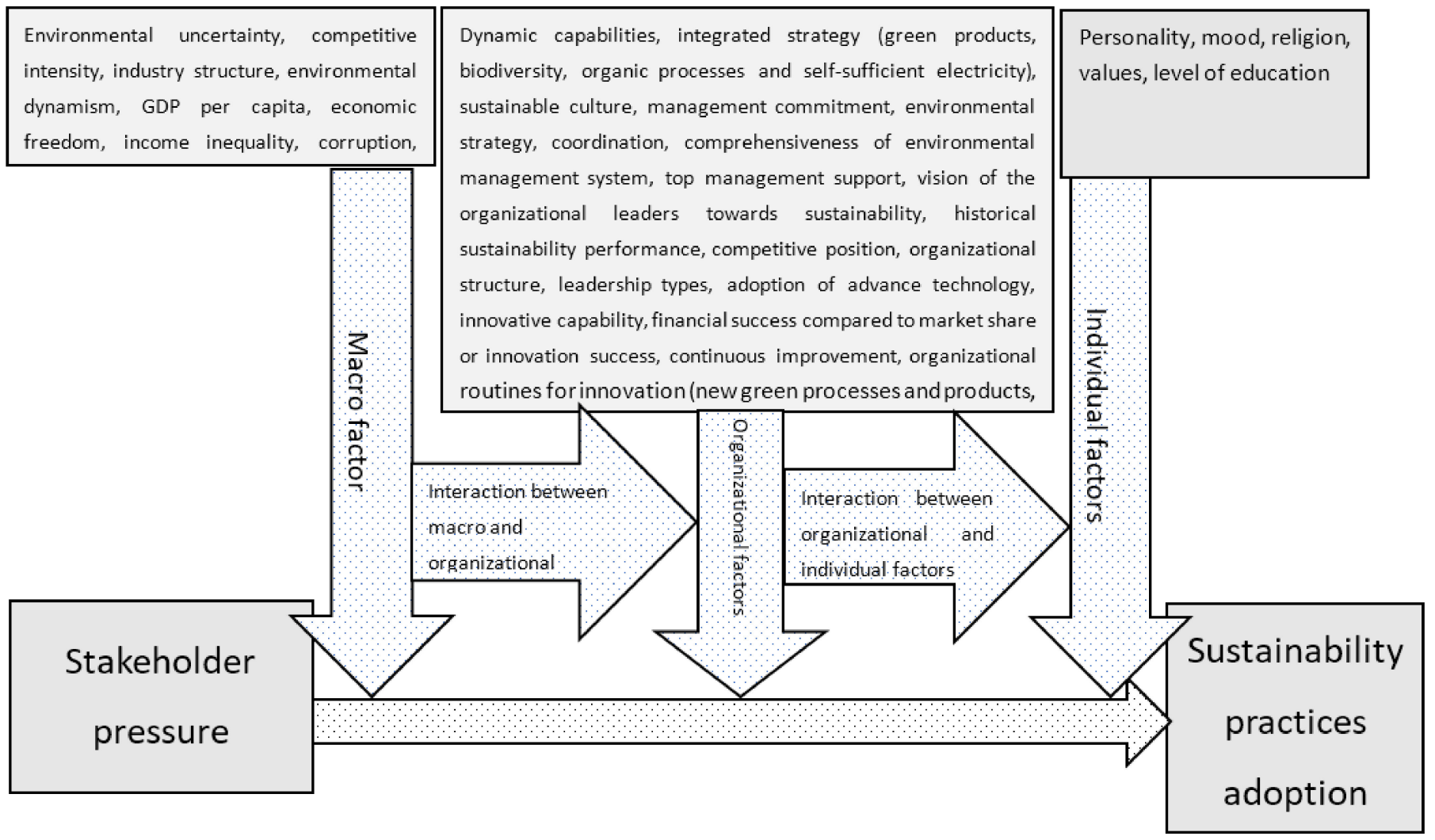

\section{References}

1. Muthuri, J.N.; Gilbert, V. An institutional analysis of corporate social responsibility in Kenya. J. Bus. Ethics 2011, 98, 467-483. [CrossRef]

2. Graham, S. The influence of external and internal stakeholder pressures on the implementation of upstream environmental supply chain practices. Bus. Soc. 2020, 59, 351-383. [CrossRef]

3. Surroca, J.; Tribó, J.A.; Zahra, S.A. Stakeholder pressure on MNEs and the transfer of socially irresponsible practices to subsidiaries. Acad. Manag. J. 2013, 56, 549-572. [CrossRef]

4. Gimenez, C.; Tachizawa, E.M. Extending sustainability to suppliers: A systematic literature review. Supply Chain Manag. Int. J. 2012, 17, 531-543. [CrossRef]

5. Lee, J.W.; Kim, Y.M.; Kim, Y.E. Antecedents of adopting corporate environmental responsibility and green practices. J. Bus. Ethics 2018, 148, 397-409. [CrossRef]

6. Freeman, R.E. Strategic Management: A Stakeholder Approach; Pitman: Boston, MA, USA, 1984

7. Freeman, R.E. The stakeholder approach revisited. Z. Wirtsch. Unternehm. 2004, 5, 228-241. [CrossRef]

8. Freeman, R.E.; McVea, J.A. A stakeholder approach to strategic management. In The Blackwell Handbook of Strategic Management; Hitt, M., Freeman, R.E., Harrison, J., Eds.; Wiley-Blackwell: Oxford, UK, 2001; pp. 189-207.

9. Gonzalez-Benito, J.; Gonzalez-Benito, O. The role of stakeholder pressure and managerial values in the implementation of environmental logistics practices. Int. J. Prod. Res. 2006, 44, 1353-1373. [CrossRef]

10. Wolf, J. The relationship between sustainable supply chain management, stakeholder pressure and corporate sustainability performance. J. Bus. Ethics 2014, 119, 317-328. [CrossRef]

11. Zhu, Q.; Sarkis, J.; Geng, Y. Green supply chain management in China: Pressures, practices and performance. Int. J. Oper. Prod. Manag. 2005, 25, 449-468. [CrossRef]

12. Zhu, Q.; Sarkis, J. An inter-sectoral comparison of green supply chain management in China: Drivers and practices. J. Clean. Prod. 2006, 14, 472-486. [CrossRef]

13. Sarkis, J.; Gonzalez-Torre, P.; Adenso-Diaz, B. Stakeholder pressure and the adoption of environmental practices: The mediating effect of training. J. Oper. Manag. 2010, 28, 163-176. [CrossRef] 
14. Sancha, C.; Longoni, A.; Giménez, C. Sustainable supplier development practices: Drivers and enablers in a global context. J. Purch. Supply Manag. 2015, 21, 95-102. [CrossRef]

15. Zhu, Q.; Sarkis, J.; Lai, K.H. Institutional-based antecedents and performance outcomes of internal and external green supply chain management practices. J. Purch. Supply Manag. 2013, 19, 106-117. [CrossRef]

16. Denend, L. Walmart's Sustainability Strategy; Stanford Graduate School of Management, Stanford University: Stanford, CA, USA, 2007; pp. 1-50.

17. Meixell, M.J.; Luoma, P. Stakeholder pressure in sustainable supply chain management: A systematic review. Int. J. Phys. Distrib. Logist. Manag. 2015, 45, 69-89. [CrossRef]

18. Miemczyk, J.; Johnsen, T.E.; Macquet, M. Sustainable purchasing and supply management: A structured literature review of definitions and measures at the dyad, chain and network levels. Supply Chain Manag. Int. J. 2012, 17, 478-496. [CrossRef]

19. Salvador, R.; Barros, M.V.; da Luz, L.M.; Piekarski, C.M.; de Francisco, A.C. Circular business models: Current aspects that influence implementation and unaddressed subjects. J. Clean. Prod. 2019, 250, 119555. [CrossRef]

20. Sarkis, J.; Zhu, Q.; Lai, K. An organizational theoretic review of green supply chain management literature. Int. J. Prod. Econ. 2011, 130, 1-15. [CrossRef]

21. Terán-Yépez, E.; Marín-Carrillo, G.M.; del Pilar Casado-Belmonte, M.; de las Mercedes Capobianco-Uriarte, M. Sustainable entrepreneurship: Review of its evolution and new trends. J. Clean. Prod. 2020, 252, 119742. [CrossRef]

22. Fink, A. Conducting Research Literature Review: From Paper to the Internet; Sage Publications: Thousand Oaks, CA, USA, 2005.

23. Denyer, D.; Tranfield, D. Producing a systematic review. In The Sage Handbook of Organizational Research Methods; Buchanan, D., Bryman, A., Eds.; Sage Publications Ltd.: London, UK, 2009.

24. Meredith, J. Theory building through conceptual methods. Int. J. Oper. Prod. Manag. 1993, 13, 3-11. [CrossRef]

25. Bortz, J.; Doring, N. Forschungsmethoden und Evaluation für Human-und Sozialwissenschaftler. In Research Methods and Evaluation in Human and Social Sciences, 4th ed.; Springer: Berlin/Heidelberg, Germany, 2006.

26. Teuteberg, F.; Wittstruck, D. A Systematic Review of Sustainable Supply Chain Management Research. What Is There and what Is Missing? In Multikonferenz Wirtschaftsinformatik; Universitatsverlag Gottingen: Gottingen, Germany, 2010.

27. Catuogno, S.; Saggese, S.; Sarto, F. Alignment vs. rent-extraction effects of stock options. A conceptual model. Corp. Gov. 2016, 16, 693-708. [CrossRef]

28. Marceau, K.; Hottle, S.; Yatcilla, J.K. Puberty in the last 25 years: A retrospective bibliometric analysis. J. Res. Adolesc. 2019, 29, 96-114. [CrossRef]

29. Xu, Y.; Zeng, J.; Chen, W.; Jin, R.; Li, B.; Pan, Z. A holistic review of cement composites reinforced with graphene oxide. Constr. Build. Mater. 2018, 171, 291-302. [CrossRef]

30. Australian Business Dean's Council. ABDC Journal Quality List. 2019. Available online: https://abdc.edu.au/research/abdcjournal-list/ (accessed on 21 December 2020).

31. Ashby, A.; Leat, M.; Hudson-Smith, M. Making connections: A review of supply chain management and sustainability literature. Int. J. Supply Chain Manag. 2012, 17, 497-516. [CrossRef]

32. Tranfield, D.; Denyer, D.; Smart, P. Towards a methodology for developing evidence-informed management knowledge by means of systematic review. Br. J. Manag. 2003, 14, 207-222. [CrossRef]

33. Carroll, A.B.; Shabana, K.M. The business case for corporate social responsibility: A review of concepts, research and practice. Int. J. Manag. Rev. 2010, 12, 85-105. [CrossRef]

34. Sharma, S.; Henriques, I. Stakeholder influences on sustainability practices in the Canadian forest products industry. Strateg. Manag. J. 2005, 26, 159-180. [CrossRef]

35. Bansal, P. Evolving sustainably: A longitudinal study of corporate sustainable development. Strateg. Manag. J. 2005, 26, 197-218. [CrossRef]

36. Ouyang, Z.; Cheng, P.; Liu, Y.; Yang, R. Institutional drivers for corporate philanthropic activities in China: Mediating roles of top management participation. Corp. Soc. Responsib. Environ. 2020, 27, 244-255. [CrossRef]

37. Baah, C.; Jin, Z.; Tang, L. Organizational and regulatory stakeholder pressures friends or foes to green logistics practices and financial performance: Investigating corporate reputation as a missing link. J. Clean. Prod. 2020, 247, 119-125. [CrossRef]

38. Nguyen, N.P.; Adomako, S. Stakeholder pressure for eco-friendly practices, international orientation, and eco-innovation: A study of small and medium-sized enterprises in Vietnam. Corp. Soc. Responsib. Environ. 2021, 29, 79-88. [CrossRef]

39. Daddi, T.; Bleischwitz, R.; Todaro, N.M.; Gusmerotti, N.M.; De Giacomo, M.R. The influence of institutional pressures on climate mitigation and adaptation strategies. J. Clean. Prod. 2020, 244, 118879. [CrossRef]

40. Jakhar, S.K.; Mangla, S.K.; Luthra, S.; Kusi-Sarpong, S. When stakeholder pressure drives the circular economy: Measuring the mediating role of innovation capabilities. Manag. Decis. 2019, 57, 904-920. [CrossRef]

41. Jiao, J.; Liu, C.; Xu, Y. Effects of stakeholder pressure, managerial perceptions, and resource availability on sustainable operations adoption. Bus. Strategy Environ. 2020, 29, 3246-3260. [CrossRef]

42. Qiu, L.; Hu, D.; Wang, Y. How do firms achieve sustainability through green innovation under external pressures of environmental regulation and market turbulence? Bus. Strategy Environ. 2020, 29, 2695-2714. [CrossRef]

43. Gong, M.; Gao, Y.; Koh, L.; Sutcliffe, C.; Cullen, J. The role of customer awareness in promoting firm sustainability and sustainable supply chain management. Int. J. Prod. Econ. 2019, 217, 88-96. [CrossRef] 
44. Charan, P.; Murty, L.S. Secondary stakeholder pressures and organizational adoption of sustainable operations practices: The mediating role of primary stakeholders. Bus. Strategy Environ. 2018, 27, 910-923.

45. Böttcher, C.F.; Müller, M. Drivers, practices and outcomes of low-carbon operations: Approaches of German automotive suppliers to cutting carbon emissions. Bus. Strategy Environ. 2015, 24, 477-498. [CrossRef]

46. Huang, Y.C.; Huang, C.H.; Yang, M.L. Drivers of green supply chain initiatives and performance. Int. J. Phys. Distrib. 2017, 47, 796-819. [CrossRef]

47. Carrillo-Higueras, F.; Prajogo, D.; Smith, L. Environmental commitment and its drivers in the Australian wine industry: A behavioural approach. Australas. J. Environ. Manag. 2018, 25, 439-458. [CrossRef]

48. Yu, Y.; Choi, Y. Stakeholder pressure and CSR adoption: The mediating role of organizational culture for Chinese companies. Soc. Sci. J. 2016, 53, 226-235. [CrossRef]

49. Dubey, R.; Gunasekaran, A.; Childe, S.J.; Papadopoulos, T.; Helo, P. Supplier relationship management for circular economy: Influence of external pressures and top management commitment. Manag. Decis. 2019, 57, 767-790. [CrossRef]

50. Bamgbade, J.; Kamaruddeen, A.; Nawi, M.; Adeleke, A.; Salimon, M.G.; Ajibike, W. Analysis of some factors driving ecological sustainability in construction firms. J. Clean. Prod. 2019, 208, 1537-1545. [CrossRef]

51. Jazairy, A.; von Haartman, R. Analysing the institutional pressures on shippers and logistics service providers to implement green supply chain management practices. Int. J. Logist. Res. 2020, 23, 44-84. [CrossRef]

52. Gao, Y.; Gu, J.; Liu, H. Interactive effects of various institutional pressures on corporate environmental responsibility: Institutional theory and multilevel analysis. Bus. Strategy Environ. 2019, 28, 724-736. [CrossRef]

53. Caldera, H.; Desha, C.; Dawes, L. Evaluating the enablers and barriers for successful implementation of sustainable business practice in 'lean' SMEs. J. Clean. Prod. 2019, 218, 575-590. [CrossRef]

54. Xiao, C.; Wang, Q.; van Donk, D.P.; van der Vaart, T. When are stakeholder pressures effective? An extension of slack resources theory. Int. J. Prod. Econ. 2018, 199, 138-149. [CrossRef]

55. Wang, S.; Li, J.; Zhao, D. Institutional pressures and environmental management practices: The moderating effects of environmental commitment and resource availability. Bus. Strategy Environ. 2018, 27, 52-69. [CrossRef]

56. Dubey, R.; Gunasekaran, A.; Childe, S.J.; Papadopoulos, T.; Hazen, B.; Giannakis, M.; Roubaud, D. Examining the effect of external pressures and organizational culture on shaping performance measurement systems (PMS) for sustainability benchmarking: Some empirical findings. Int. J. Prod. Econ. 2017, 193, 63-76. [CrossRef]

57. Li, D.; Zheng, M.; Cao, C.; Chen, X.; Ren, S.; Huang, M. The impact of legitimacy pressure and corporate profitability on green innovation: Evidence from China top 100. J. Clean. Prod. 2017, 141, 41-49. [CrossRef]

58. Huang, X.; Tan, B.L.; Ding, X. An exploratory survey of green supply chain management in Chinese manufacturing small and medium-sized enterprises: Pressures and drivers. J. Manuf. Technol. Manag. 2015, 26, 80-103. [CrossRef]

59. Agan, Y.; Acar, M.F.; Borodin, A. Drivers of environmental processes and their impact on performance: A study of Turkish SMEs. J. Clean. Prod. 2010, 51, 23-33. [CrossRef]

60. Darnall, N.; Henriques, I.; Sadorsky, P. Adopting proactive environmental strategy: The influence of stakeholders and firm size. J. Manag. Stud. 2010, 47, 1072-1094. [CrossRef]

61. Seroka-Stolka, O.; Fijorek, K. Enhancing corporate sustainable development: Proactive environmental strategy, stakeholder pressure and the moderating effect of firm size. Bus. Strategy Environ. 2020, 29, 2338-2354. [CrossRef]

62. Azadegan, A.; Golara, S.; Kach, A.; Mousavi, N. Corporate environmental investments: A cross-national study on managerial decision making. Int. J. Prod. Econ. 2018, 199, 47-64. [CrossRef]

63. Del Mar Miras-Rodríguez, M.; Machuca, J.A.; Escobar-Pérez, B. Drivers that encourage environmental practices in manufacturing plants: A comparison of cultural environments. J. Clean. Prod. 2018, 179, 690-703. [CrossRef]

64. González-Benito, J.; González-Benito, Ó. A study of determinant factors of stakeholder environmental pressure perceived by industrial companies. Bus. Strategy Environ. 2010, 19, 164-181. [CrossRef]

65. Park, B.I.; Ghauri, P.N. Determinants influencing CSR practices in small and medium sized MNE subsidiaries: A stakeholder perspective. J. World Bus. 2015, 50, 192-204. [CrossRef]

66. Maas, S.; Schuster, T.; Hartmann, E. Stakeholder Pressures, Environmental Practice Adoption and Economic Performance in the German Third-party Logistics Industry-A Contingency Perspective. J. Bus. Econ. 2018, 88, 167-201. [CrossRef]

67. Betts, T.K.; Wiengarten, F.; Tadisina, S.K. Exploring the impact of stakeholder pressure on environmental management strategies at the plant level: What does industry have to do with it? J. Clean. Prod. 2015, 92, 282-294. [CrossRef]

68. Berrone, P.; Fosfuri, A.; Gelabert, L.; Gomez-Mejia, L.R. Necessity as the mother of green inventions: Institutional pressures and environmental innovations. Strateg. Manag. J. 2013, 34, 891-909. [CrossRef]

69. Garcés-Ayerbe, C.; Rivera-Torres, P.; Murillo-Luna, J.L. Stakeholder pressure and environmental proactivity: Moderating effect of competitive advantage expectations. Manag. Decis. 2012, 50, 189-206. [CrossRef]

70. Ayuso, S.; Roca, M.; Colomé, R. SMEs as "transmitters" of CSR requirements in the supply chain. Int. J. Supply Chain Manag. 2013, 18, 497-508. [CrossRef]

71. Berg, N.; Holtbrügge, D.; Egri, C.P.; Furrer, O.; Sinding, K.; Dögl, C. Stakeholder pressures, CSR practices, and business outcomes in Denmark, Germany and the Netherlands. Eur. J. Int. Manag. 2018, 12, 472-500. [CrossRef]

72. Chu, Z.; Wang, L.; Lai, F. Customer pressure and green innovations at third party logistics providers in China: The moderation effect of organizational culture. Int. J. Logist. Manag. 2019, 30, 57-75. [CrossRef] 
73. Choi, S.B.; Feng, Y.; Liu, J.; Zhu, Q. Motivating corporate social responsibility practices under customer pressure among small-and medium-sized suppliers in China: The role of dynamic capabilities. Corp. Soc. Responsib. Environ. 2019, 26, 213-226. [CrossRef]

74. Liu, Y. Exploring the Relationship between External Positive-Negative Pressures and the Carbon Management Behaviour of Industrial Firm. Corp. Soc. Responsib. Environ. 2018, 25, 628-641. [CrossRef]

75. Örtenblad, A. Introduction: Establishing the art of contextualizing CSR as research area. In The Research Handbook on Corporate Social Responsibility in Context; Örtenblad, A., Ed.; Edward Elgar Publishing: Cheltenham, UK, 2016; pp. 1-14.

76. Hartmann, J.; Germain, R.; Grobecker, A. Antecedents of environmentally conscious operations in transitioning economies: Insights from Russia. Int. J. Oper. Prod. Manag. 2015, 35, 843-865. [CrossRef]

77. Christ, K.L.; Burritt, R.L. Environmental management accounting: The significance of contingent variables for adoption. J. Clean. Prod. 2013, 41, 163-173. [CrossRef]

78. Phan, T.N.; Baird, K.; Su, S. The use and effectiveness of environmental management accounting. Australas. J. Environ. Manag. 2017, 24, 355-374. [CrossRef]

79. Ramsheva, Y.K.; Prosman, E.J.; Waehrens, B.V. Dare to make investments in industrial symbiosis? A conceptual framework and research agenda for developing trust. J. Clean. Prod. 2019, 223, 989-997. [CrossRef]

80. Delmas, M.; Toffel, M.W. Stakeholders and environmental management practices: An institutional framework. Bus. Strategy Environ. 2004, 13, 209-222. [CrossRef]

81. Hult, G.T.M.; Hurley, R.F.; Knight, G.A. Innovativeness: Its antecedents and impact on business performance. Ind. Mark. Manag. 2004, 33, 429-438. [CrossRef]

82. Lozano, R. A holistic perspective on corporate sustainability drivers. Corp. Soc. Responsib. Environ. 2015, 22, 32-44. [CrossRef]

83. Hofmann, K.H.; Theyel, G.; Wood, C.H. Identifying firm capabilities as drivers of environmental management and sustainability practices-Evidence from small and medium-sized manufacturers. Bus. Strategy Environ. 2012, 21, 530-545. [CrossRef]

84. Tatoglu, E.; Frynas, J.G.; Bayraktar, E.; Demirbag, M.; Sahadev, S.; Doh, J.; Koh, S.L. Why do emerging market firms engage in voluntary environmental management practices? A strategic choice perspective. Br. J. Manag. 2020, 31, 80-100. [CrossRef]

85. Cezarino, L.O.; Alves, M.F.R.; Caldana, A.C.F.; Liboni, L.B. Dynamic Capabilities for Sustainability: Revealing the Systemic Key Factors. Syst. Pract. Action Res. 2019, 32, 93-112. [CrossRef]

86. Golicic, S.L.; Smith, C.D. A meta-analysis of environmentally sustainable supply chain management practices and firm performance. J. Supply Chain Manag. 2013, 49, 78-95. [CrossRef]

87. Aguilera, R.V.; Williams, C.A.; Conley, J.M.; Rupp, D.E. Corporate governance and social responsibility: A comparative analysis of the UK and the US. Corp. Gov. Int. Rev. 2006, 14, 147-158. [CrossRef]

88. Baughn, C.C.; Bodie, N.L.; McIntosh, J.C. Corporate social and environmental responsibility in Asian countries and other geographical regions. Corp. Soc. Responsib. Environ. Manag. 2007, 14, 189-205. [CrossRef]

89. Aguinis, H.; Glavas, A. What we know and don't know about corporate social responsibility: A review and research agenda. $J$. Manag. 2012, 38, 932-968. [CrossRef]

90. Banerjee, R.; Gupta, K.; McIver, R. What matters most to firm-level environmentally sustainable practices: Firm-Specific or country-Level factors? J. Clean. Prod. 2019, 218, 225-240. [CrossRef]

91. Sanchez, R.G.; Bolivar, M.P.R.; Hernández, A.M.L. Perceptions of stakeholder pressure for supply-chain social responsibility and information disclosure by state-owned enterprises. Int. J. Logist. Manag. 2017, 28, 1027-1053. [CrossRef]

92. Shnayder, L.; Van Rijnsoever, F.J.; Hekkert, M.P. Motivations for Corporate Social Responsibility in the packaged food industry: An institutional and stakeholder management perspective. J. Clean. Prod. 2016, 122, 212-227. [CrossRef]

93. Delmas, M.A. Stakeholders and competitive advantage: The case of ISO 14001. Int. J. Oper. Prod. Manag. 2001, 10, 343-358. [CrossRef]

94. Ehrgott, M.; Reimann, F.; Kaufmann, L.; Carter, C.R. Social sustainability in selecting emerging economy suppliers. J. Bus. Ethics 2011, 98, 99-119. [CrossRef]

95. Engert, S.; Rauter, R.; Baumgartner, R.J. Exploring the integration of corporate sustainability into strategic management: A literature review. J. Clean. Prod. 2016, 112, 2833-2850. [CrossRef]

96. Hart, S. A natural-resource-based view of the firm. Acad. Manag. Rev. 1995, 20, 968-1014. [CrossRef]

97. Suchman, M.C. Managing legitimacy: Strategic and institutional approaches. Acad. Manag. Rev. 1995, 20, 571-610. [CrossRef]

98. Dowling, J.; Pfeffer, J. Organization legitimacy: Social values and organizational behaviour. Pac. Sociol. Rev. 1975, 28, 122-136. [CrossRef]

99. Parsons, T. Suggestions for A Sociological Approach to the Theory of Organizations. Adm. Sci. Q. 1956, 1, 63-85. [CrossRef]

100. Weber, M. Economy and Society; Roth, G., Wittich, C., Eds.; University of California Press: Oakland, CA, USA, 1978.

101. Czinkota, M.; Kaufmann, H.R.; Basile, G. The relationship between legitimacy, reputation, sustainability and branding for companies and their supply chains. Ind. Mark. Manag. 2014, 43, 91-101. [CrossRef]

102. Deegan, C.; Rankin, M.; Tobin, J. An examination of the corporate social and environmental disclosures of BHP from 1983-1997: A test of legitimacy theory. Account. Audit. Account. J. 2002, 15, 312-343. [CrossRef]

103. Scott, W.R. Institutions and Organizations: Ideas, Interests, and Identities; Sage Publication: Thousand Oaks, CA, USA, 2014.

104. Dutta, S.; Lawson, R.; Marcinko, D. Paradigms for sustainable development: Implication of management theory. Corp. Soc. Responsib. Environ. Manag. 2012, 19, 1-10. [CrossRef] 
105. McCuddy, M.K.; Pirie, W.L. Spirituality, stewardship, and financial decision-making: Toward a theory of intertemporal stewardship. Manag. Financ. Rev. 2007, 33, 957-969.

106. Hernandez, M. Toward an understanding of the psychology of stewardship. Acad. Manag. Rev. 2012, 37, 172-193. [CrossRef]

107. Marshall, R.S.; Akoorie, M.E.; Hamann, R.; Sinha, P. Environmental practices in the wine industry: An empirical application of the theory of reasoned action and stakeholder theory in the United States and New Zealand. J. World Bus. 2010, 45, 405-414. [CrossRef]

108. Ajzen, I.; Fishbein, M. Understanding Attitudes and Predicting Social Behavior; Prentice-Hall: Englewood Cliffs, NJ, USA, 1980.

109. Ajzen, I. A theory of planned behavior. Organ. Behav. Hum. Decis. Process. 1991, 50, 179-211. [CrossRef]

110. Donaldson, L.; Davis, J. Stewardship of agency theory: CEO governance and shareholder returns. Am. J. Manag. 1991, 16, 49-64. [CrossRef]

111. Gunarathne, N.; Lee, K.H. Institutional pressures and corporate environmental management maturity. Manag. Environ. Qual. Int. J. 2019, 30, 157-175. [CrossRef]

112. Lucas, M.T.; Wilson, M.A. Tracking the relationship between environmental management and financial performance in the service industry. Serv. Bus. 2008, 2, 203-218. [CrossRef]

113. Moreno, E.C.; Lorente, J.S.; Nez, J.D.B.J. Environmental strategies in Spanish hotels: Contextual factors and performance. Serv. Ind. J. 2004, 24, 101-130. [CrossRef]

114. Foster, S.T.; Sampson, S.E.; Dunn, S.C. The impact of customer contact on environmental initiatives for service firms. Int. J. Oper. Prod. Manag. 2000, 20, 187-203. [CrossRef]

115. Merchant, H.; Gaur, A.S. Opening the 'non-manufacturing' envelope: The next big enterprise for international business research. Manag. Int. Rev. 2008, 48, 379-396. [CrossRef]

116. Hsu, C.C.; Tan, K.C.; Zailani, S.H.M.; Jayaraman, V. Supply chain drivers that foster the development of green initiatives in an emerging economy. Int. J. Oper. 2013, 33, 656-688. [CrossRef]

117. Vanalle, R.M.; Ganga, G.M.; Filho, M.G.; Lucato, W.C. Green supply chain management: An investigation of pressures, practices, and performance within the Brazilian automotive supply chain. J. Clean. Prod. 2017, 151, 250-259. [CrossRef]

118. Galeazzo, A.; Klassen, R.D. Organizational context and the implementation of environmental and social practices: What are the linkages to manufacturing strategy? J. Clean. Prod. 2015, 108, 158-168. [CrossRef]

119. Haleem, F.; Farooq, S.; Wæhrens, B.V. Supplier corporate social responsibility practices and sourcing geography. J. Clean. Prod. 2017, 153, 92-103. [CrossRef]

120. Huq, F.A.; Chowdhury, I.N.; Klassen, R.D. Social management capabilities of multinational buying firms and their emerging market suppliers: An exploratory study of the clothing industry. J. Oper. Manag. 2016, 46, 19-37. [CrossRef]

121. Taghian, M.; D'Souza, C.; Polonsky, M. A stakeholder approach to corporate social responsibility, reputation and business performance. Soc. Responsib. J. 2015, 11, 340-363. [CrossRef] 